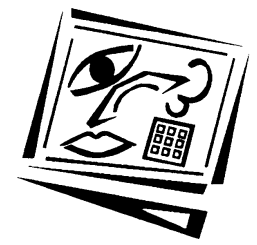

\title{
Netbooks in sixth-grade English language classrooms
}

Janet Mei-Chuen Lin and Yi-Jiun Wu National Taiwan Normal University

\begin{abstract}
As netbook computers are becoming an attractive option for K-12 educators, they have the potential to be a more integral part of language learning. In this study 45 sixth graders in two classes used netbooks to learn English as a second language. Forty-four students in two other classes served as the control group who received traditional instruction. It was found that the use of netbooks encouraged the instructor to design more innovative learning activities which greatly enhanced student engagement in learning. The activities provided students with much more opportunities to practice listening and speaking. A questionnaire survey and individual interviews showed that the netbook-using students not only liked English language class more and were more attentive during class but were more confident in being able to learn English language well. It was also revealed that the netbook-using students significantly outscored their non-netbook-using counterparts. These encouraging findings confirm the potential benefits of netbooks in language classrooms. However, this study also discovers some possible problems of implementing netbook-supported learning activities, including increased classroom inefficiencies caused by unstable network connectivity and slow boot and application load time, the increased anxiety felt by the participating teacher, and the extra effort needed to gain parental support on the use of netbooks in class.
\end{abstract}

\section{Introduction}

With the falling prices of laptop computers, one-to-one computer initiatives for K-12 students and educators have become widely established around the world. For example, many states in the United States, including Maine, Virginia, New Orleans, Louisiana, Texas, Florida, New Hampshire, and California, have been implementing such programs, in which all students are provided a laptop for use throughout the school day and often at home too. Another common method of laptop technology implementation is to acquire classroom sets of laptops, stored on a mobile recharging cart, for use by any classroom in a school. Whichever method is adopted, these initiatives have made the tools for learning available right where students work, not in separated computer labs. This has been seen as one of the most compelling schoolchange interventions in decades (Rockman, 2003).

Researchers have found consistently positive results from classrooms participating in laptop projects (e.g., Barrios, et al., 2004; Grimes \& Warschauer, 2008; Hinson \& CrainDorough, 2009; Mouza, 2008; Rockman, 2003; Silvernail, 2005; Suhr, Hernandez, Grimes \& Warschauer, 2010; Warschauer, Grant, Del Real \& Rousseau, 2004; Zucker \& McGhee, 2005). Benefits claimed included greater access to online resources, increased student engagement, reduced digital divide, development of students' 21st-century skills (e.g., problem solving, communications, self management, and thinking), qualitatively better writing skills, and gains in state standardised tests. Integration of laptops into higher education has also seen significant improvements in student 
learning (e.g., Efaw, Hampton, Martinez \& Smith, 2004). The inception of the even smaller, lighter, and less expensive netbooks in late 2007 has reduced the financial burden of one-to-one education further. Cramer, Beauregard, \& Sharma (2009) have found the design of netbooks appropriate and engaging for the unique needs of primary school students.

Laptops have also proven their potential to become a more integral part of language learning. For example, in Warschauer, Grant, Del Real \& Rousseau's study (2004), two K-12 schools used technology, including a laptop computer for each student, toward the development of English language learners' language proficiency and academic literacy. The use of technology was found to result in sophisticated student products, highly engaged learners, and high standardised test scores in relationship to school demographics. The authors emphasised that the success of the laptop program was due to teachers' deliberate integration of technology into the reading/language arts curriculum. According to McGrail (2006), most secondary English teachers saw the benefits of laptop technology in addressing individual students' learning needs, raising their self esteem, improving certain language and study skills, and supporting constructivist pedagogy. However, these teachers also revealed a great deal of ambivalence about technology in English instruction in the context of a school-wide laptop initiative. The reasons cited included teachers' having little control over the decision to join the laptop program, the conflicts surrounding standardised tests' uncertain relationship with technology mandates, the institutional pressure to use the technology most of the time in disregard of teachers' perception about the degree of its use in the classroom, and the difficulties that some teachers faced for having to follow the curriculum and integrate the technology at the same time.

Godwin-Jones (2008) analysed the "lighter, faster, smarter" mobile-computing trends and pointed out that the changing computing and networking environment had opened up new vistas for language learning. Regarding the use of mobile devices in EFL (English as a foreign language) teaching and learning, many researchers adopted mobile phones. For example, Thornton and Houser (2005) carried out the LOTM project in which the researchers emailed 100-word English vocabulary mini-lessons three times a day to the mobile phones of 44 Japanese university students in two EFL classes. It was found that delivery of vocabulary lessons via mobile phone email was effective in promoting regular study; in addition, students who received mobile email learned more than other students who were urged to regularly study identical materials on paper or the web. Similarly, Lu (2008) explored the application of the short message service (SMS) in EFL learning in Taiwan by sending SMS vocabulary lessons to 30 vocational high school students. The results showed that students recognised more vocabulary through reading SMS lessons than they did through reading the relatively more detailed print material. The participants also held positive attitudes toward learning vocabulary via mobile phones.

Some other researchers adopted tablet PCs in EFL teaching and learning for its userfriendlier bigger screen size, as compared with hand-held devices. In Lan, Sung \& Chang's study (2007), a mobile device supported, peer assisted learning (MPAL) system was developed to support collaborative reading activities for beginning level EFL learners, using tablet PCs. It was found that MPAL seemingly reduced students' anxiety, enhanced their motivation to learn, increased their confidence in oral reading, and facilitated collaboration among students. Students, especially low and medium achievers, also became more attentive to the assigned reading tasks. Hung, Young and 
Lin (2009) investigated if 32 sixth graders who used a face to face collaborative English vocabulary acquisition game system, called WiCFG, installed on tablet PCs would be more motivated to learn English vocabulary. Their findings indicated that WiCFG helped to engage students in learning and improve their motivation.

As a more recently developed portable device, netbooks offer almost all the features that one will need from a small portable computer at very affordable prices. They have potential for further enriching the language learning experiences of students. However, studies on the use of netbooks in EFL classrooms have hardly been reported in the literature so far. The purpose of this study is to investigate how netbooks can be integrated into EFL teaching and learning in an elementary school in Taiwan. Specifically, we aim to understand what kinds of learning activities the instructor would design around the use of netbooks and how the use of netbooks would impact on student learning in terms of students' performance in exams, their attitude toward English learning, and their classroom behaviour.

\section{Method}

In this study we conducted a quasi-experiment which involved 89 sixth graders (age range 11-12 years) in four intact classes in an elementary school in Taipei, Taiwan. Two of the four classes, with a total of 45 students, were randomly selected to be the experimental group; the other two classes, with a total of 44 students, served as the control group. Students in the experimental group were paired up and each pair was provided an Acer Aspire One with the traditional Chinese version of Windows XP installed on it. In contrast, students in the control group received traditional instruction. All students had the signed parental consent forms to take part in this research.

To ensure comparability of English language ability between the two groups, all the participants were given a pre-test. No statistically significant difference was found between the experimental group $(M=42.13, S D=11.11)$ and the control group $(M=$ $39.61, S D=10.47$ ), indicating that the two groups were comparable in their English ability before the experiment was conducted.

The experiment was carried out from February to June 2009 for 19 weeks. English language was taught to the participants for two 40-minute periods per week. Netbooks were distributed to students in the experimental group at the beginning of each class and collected at the end of the class. The netbooks were put on students' desks with lid closed and were to be opened only when instructed by the teacher to perform certain learning activities, as will be described later. Students in the control group received traditional instruction in which textbooks, paper-based worksheets, and CD players were used.

Data were collected during the course of the experiment through classroom observation, video recording of classroom activities, reflective journal kept (in Chinese) by the English language teacher, a questionnaire survey, a final exam, and individual interviews with the participants. Student behaviour was observed and recorded using a coded data sheet for a time sampling observation. Categories of students' classroom behaviour were defined by the researchers and the English language teacher together. A total of 12 categories were identified, including listening to lectures, reading practice, listening practice, speaking practice, paper/pencil practice, peer discussion, taking 
notes, asking questions/seeking help, answering questions posed by the teacher, distracted behaviour, miscellaneous computer-related tasks, and others. Anecdotal records documenting significant incidents occurring during class hours were also kept utilising an anecdotal observation form. Each record included the following information: name of the observer, date of the incident, time when the incident occurred, name of the student(s) involved, a description of the incident, observer's remarks, and teacher's and the involved student(s)' explanation for the incident (obtained through after-class interviews).

In order to understand if significant difference existed between the two groups in students' attitude toward English language learning, all participants were asked to fill out a 12-item questionnaire, as will be shown later in Table 2, both before and after the experiment. Each question was rated on a 4-point Likert scale (from $1=$ Strongly disagree to $4=$ Strongly agree). The overall Cronbach's coefficient alpha for the questionnaire was 0.89 .

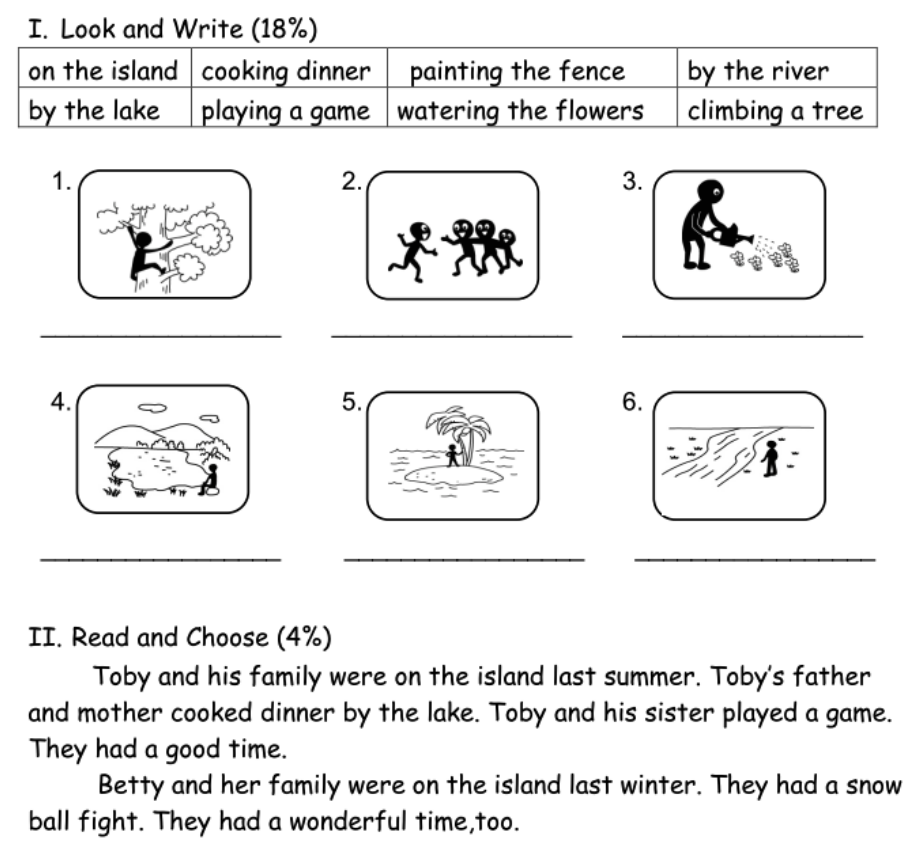

1. () Where were Betty and her family last winter?
$\begin{array}{lll}\text { (A) On the island. (B) By the lake. (C) In the mountains. }\end{array}$

2. ( ) What did Toby and his sister do on the island?

(A) They cooked dinner. (B) They had a good time. (C) They played a game.

Figure 1: The first two sections of the written test

The final exam contained two parts, written and listening, each constituting $50 \%$ of the total score. The written test comprised four sections: look and write, read and choose, read and write, and choose and write. Figure 1 shows the first two sections of the written test. The listening test was made up of six sections: listen and match, listen and choose, listen and number, listen and circle, listen and write, and listen and answer. Figure 2 shows Sections 2 and 3 of the listening test. Students' speaking ability was 
tested separately. In the speaking test the teacher conversed with each individual student using the words and sentence structures that had been taught during the semester.

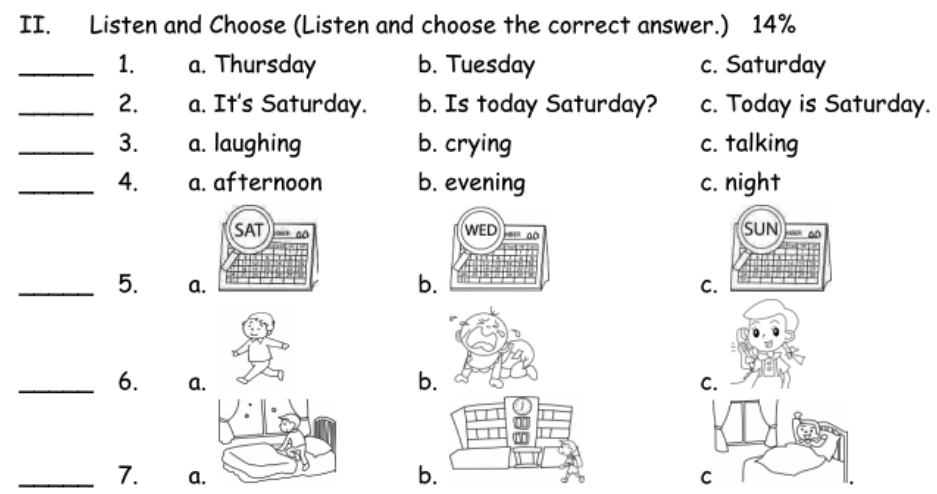

III. Listen and Number (Listen to the story and number the pictures from 1 to 5 .) $5 \%$

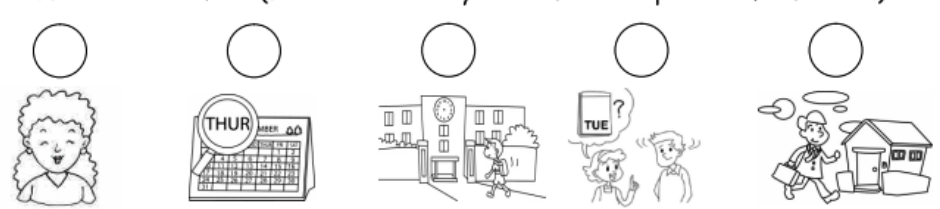

Figure 2: Sections 2 and 3 of the listening test

\section{Netbook-supported learning activities}

Before the semester started in February 2009, one of the researchers met with the participating teacher regularly during the winter break to design lesson plans and learning activities for the entire semester. Six activities aiming to engage netbook-using students in active learning were created. Students in the control group did comparable activities wherever possible, without using netbooks.

\section{Activity 1: Creating a mini online dictionary}

Each team was assigned a set of new words and idioms which they were asked to translate into Chinese using online English-Chinese dictionaries. The teacher recommended popular online dictionaries such as Google Dictionary and Yahoo! Kimo Dictionary, but students were free to choose whatever online dictionary they preferred. They then uploaded the pairs of English/Chinese words and idioms to a common workplace on the school Moodle platform, thus creating a mini online dictionary collaboratively. They were also asked to teach those new words and idioms to the class. For students in the control group, traditional lectures were given, in which the teacher introduced each new word or idiom by explaining its meaning and proper usage and leading the students in practicing its pronunciation.

\section{Activity 2: Introducing oneself}

Each student in the experimental group was required to take a picture of himself/herself with the netbook's built-in webcam. They also used the netbook's 
built-in microphone and Windows $X P^{\prime}$ s pre-loaded voice recorder software to record a brief self-introduction, which had to include one's name, favourite season of the year, and favourite school subjects. Each of them then uploaded his/her picture (in JPG format) and the recorded self-introduction (in WAV format) to the school Moodle platform. Figure 3 shows how students were making and listening to their own recordings. Students in the control group practised using correct sentence structures to introduce oneself, both orally and in writing without the help of computers or other recording devices.

\section{Activity 3: A bingo game}

In this game each team was free to select four other students' self-introductions created in Activity 2 and download them to their netbook. They needed to listen carefully to those recordings in order to answer questions posed by the teacher about a particular student's favourite season of the year or favourite school subject. Whenever the teacher asked a question, say about student X, those teams that had downloaded student X's recording and knew the answer could raise their hands, and the teacher would pick one student to answer. The team that answered a question correctly would win a "match." The teacher continued to ask questions until a team succeeded in winning four "matches" and declared Bingo. Because an exactly same game could not be easily implemented for students in the control group, the teacher designed a quiz game for them instead. She divided the control group into two teams and let them compete to answer questions using the same set of sentences used by students in the experimental group for the Bingo game.
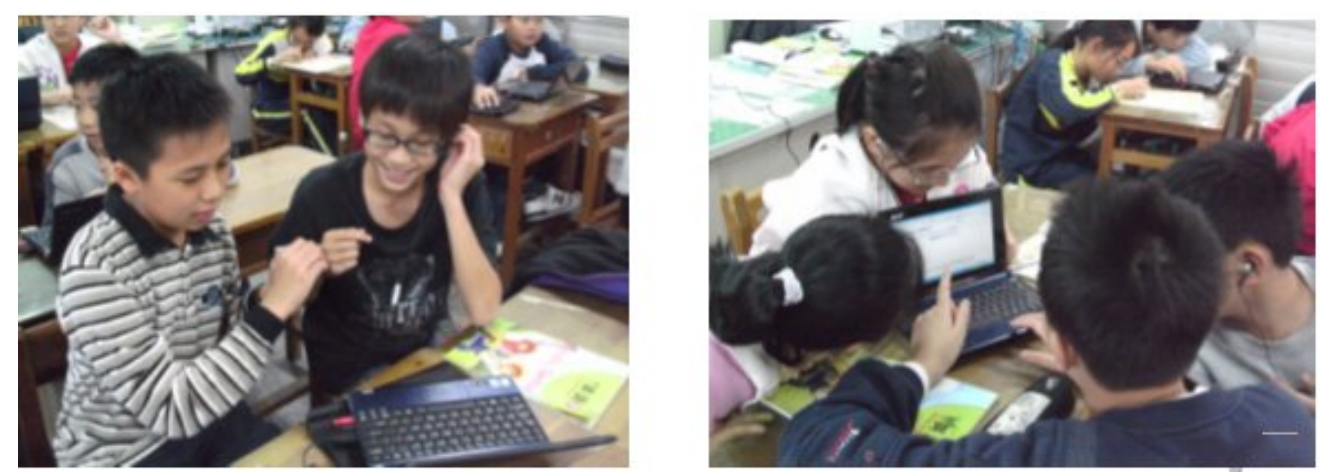

Figure 3: Recording self introductions

\section{Activity 4: Acting out short stories}

In this activity each student acted out a short story in the textbook. All other students were required to write a comment on his/her performance and assign separate scores (from 1 to 10) to each of the two criteria: pronunciation/intonation and acting skill. Students assigned scores using Moodle's poll feature, which allowed the teacher to see intuitive table view of who chose what as well as display a graph of results for each student, as shown in Figure 4. Comments were submitted in the form of posted messages to Moodle's discussion forum. Students in the control group did the same activity except that they assigned scores and gave comments on printed grading sheets. 


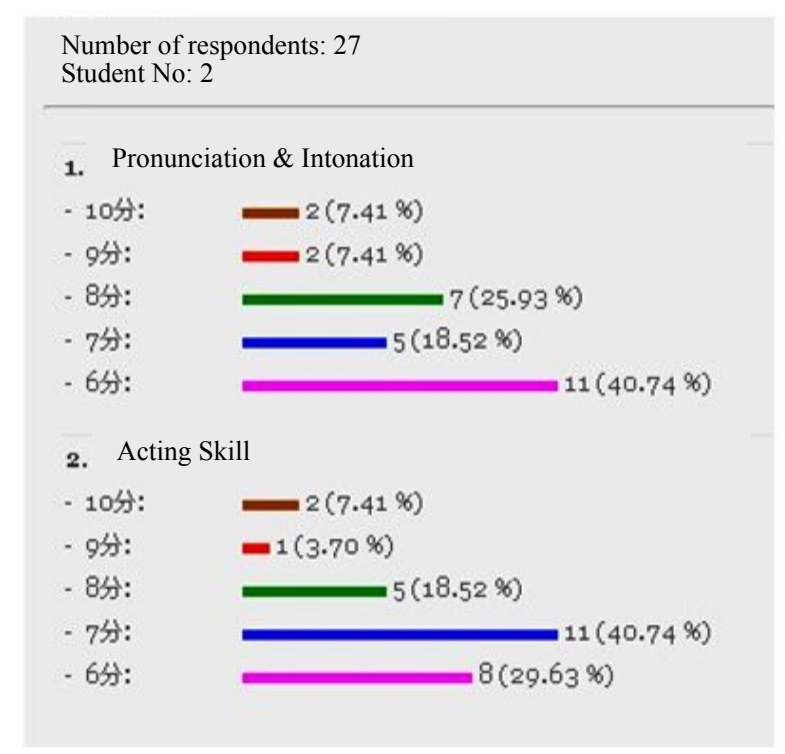

Figure 4: Tallying and displaying scores using Moodle's poll feature

\section{Activity 5: What did I do last night?}

As a preparation for the next activity, each student was asked to record a statement about what $\mathrm{s} /$ he did the night before. The recordings were uploaded so the teacher could create a suspense story from them. Students in the control group did not do any comparable activity.

\section{Activity 6: A suspense story}

The teacher created a PowerPoint presentation of a suspense story utilising the pictures students took of themselves in Activity 2 and the recordings they uploaded in Activity 5. The picture of each student was combined with the recording s/he made about what $\mathrm{s} /$ he did the night before. It was designed to look like each student was providing an alibi for an imaginary crime which the teacher had embedded in the suspense story. Students watched the PowerPoint presentation on their netbooks and had to listen carefully to all "alibis" and keep track of the clues in order to solve the mystery. To practice the same set of sentence structures, students in the control group played a tictac-toe game instead. Two teams took turns throwing a soft ball at a $3 \times 3$ grid drawn on the blackboard. When a team correctly answered the question associated with the empty space hit by the ball, the team got the mark. The team that succeeded in placing three respective marks in a row won the game.

\section{Results and discussion}

Quantitative data collected in this study include the final exam scores, results of a questionnaire survey, and frequency counts of student behaviour observed in the English language classroom. They were analysed using SPSS for Windows. The qualitative data we gathered include the reflective journal kept by the English language teacher, anecdotal records, and transcripts of individual interviews. These qualitative data were coded and analysed. Notable findings are presented below. 


\section{Final exam}

As mentioned previously, the final exam contained the written part and the listening part, each constituting 50\% of the total score, and students' speaking ability was tested separately. As Table 1 shows, there is a statistically significant difference $(T=2.218, p<$ $.05)$ between the two groups in the total score. A further analysis reveals that the difference is mainly caused by the written test, in which the experimental group $(M=$ $44.52, S D=6.66)$ significantly outscores the control group $(M=40.14, S D=10.01)$. As to listening and speaking, the mean scores of the experimental group are higher than those of the control group, but no statistically significant differences are found. Such findings are somewhat to our surprise because it was expected that netbook-using students who had more opportunities to practice listening and speaking would do better in those two tests. The English language teacher gave a possible explanation:

Students are typically more afraid to take listening and speaking tests. Therefore, I tend to make these two parts easier than the written part so as not to impede their confidence. Those two tests might have been too easy to differentiate.

Table 1: A between-group comparison of the final exam scores

\begin{tabular}{|c|c|c|c|c|c|}
\hline & \multicolumn{2}{|c|}{$\begin{array}{l}\text { Experimental group } \\
(\mathrm{N}=45)\end{array}$} & \multicolumn{2}{|c|}{$\begin{array}{c}\text { Control group } \\
(\mathrm{N}=44)\end{array}$} & \multirow[t]{2}{*}{$\mathrm{T}$} \\
\hline & Mean & SD & Mean & SD & \\
\hline Total score & 90.76 & 8.14 & 85.56 & 13.40 & $2.218^{*}$ \\
\hline Written & 44.52 & 6.66 & 40.14 & 10.01 & $2.44^{*}$ \\
\hline Listening & 46.23 & 4.03 & 44.52 & 5.06 & 0.85 \\
\hline Speaking & 90.87 & 8.50 & 87.68 & 11.38 & 1.50 \\
\hline
\end{tabular}

Some clues may be obtained from students' comments as to why the experimental group performed better in the final exam. For example,

The netbook enabled me to learn more and memorise words and sentences more easily.

I listened to my own recording and didn't find it good enough, so I did it again and again. It gave me a lot of practice....When I saw the problems on the exam paper, I knew the answers immediately because I had practised so many times.

Whenever I was not sure how to pronounce a word, I would ask the teacher right away; otherwise I would not be able to make a good recording for uploading.

\section{Attitude questionnaire}

Table 2 shows the results of the post-experiment questionnaire survey. The questions were presented to students in Chinese. The English version shown in Table 2 was translated by the authors. It can be seen that the netbook-using students were more interested in learning and using English (items 1-4); they liked English language class more and were more attentive during class (items 6-7); they were more confident in being able to learn English language well (items 9-10); and they found English language less difficult (item 11). Considering that no statistically significant difference was found between the two groups in any of these 12 questions in the pre-experiment survey, we can reasonably conclude that the difference appearing in the postexperiment survey was due to the treatment, namely the use of netbooks by the 
experimental group. However, three questions did not reveal statistically significant difference between the two groups in the post-experiment survey, indicating that the use of netbooks did not reduce students' fear of English (item 5), neither did it make the students feel less nervous during English language class (item 8). In addition, the use of netbooks did not make students study harder for the exam (item 12).

Table 2: Results of the attitude questionnaire survey

\begin{tabular}{|c|c|c|c|c|c|}
\hline \multirow[t]{2}{*}{ Items } & \multicolumn{2}{|c|}{$\begin{array}{l}\text { Experimental } \\
\text { group }(\mathrm{N}=45)\end{array}$} & \multicolumn{2}{|c|}{$\begin{array}{l}\text { Control } \\
\text { group }(\mathrm{N}=44)\end{array}$} & \multirow[t]{2}{*}{$\mathrm{T}$} \\
\hline & Mean & SD & Mean & SD & \\
\hline 1. I like English language. & 2.96 & .80 & 2.59 & .90 & $2.03^{*}$ \\
\hline 2. I like to learn English. & 3.07 & .84 & 2.59 & .79 & $2.76^{* *}$ \\
\hline 3. I like to use English. & 2.82 & .96 & 2.41 & .95 & $2.04^{*}$ \\
\hline $\begin{array}{l}\text { 4. I am interested in knowing information about } \\
\text { English. }\end{array}$ & 3.00 & .74 & 2.37 & .95 & $3.47^{* *}$ \\
\hline 5. I am scared by English. & 2.11 & 1.05 & 2.00 & .91 & .53 \\
\hline 6. I like my English language class. & 3.18 & .86 & 2.64 & .97 & $2.79^{* *}$ \\
\hline 7. I am attentive in English language class. & 3.29 & .59 & 2.78 & .83 & $3.39^{* *}$ \\
\hline 8. I felt nervous in English language class. & 2.02 & .92 & 1.95 & .96 & .34 \\
\hline 9. I can learn English. & 3.29 & .69 & 2.93 & .90 & $2.10^{*}$ \\
\hline 10. I will be successful in my English language class. & 3.33 & .64 & 2.93 & .87 & $2.48^{*}$ \\
\hline 11. English language is a difficult subject. & 2.49 & .94 & 2.89 & .92 & $-2.01^{*}$ \\
\hline 12. I studied hard for the English language tests. & 3.04 & .74 & 2.73 & .92 & 1.79 \\
\hline
\end{tabular}

$* p<.05 * * p<.01$

The English language teacher also noticed meaningful changes in some students' classroom performance. As noted in her reflective journal (translated from Chinese by the authors):

Sammy used to be very reluctant to come forward and speak English in front of the class, but he looked happy talking to the netbook. To my surprise, he raised his hand in class one day and asked me how to pronounce a new word. He even brought his netbook to me and wanted me to listen to his recordings. It seems he feels much more at ease talking to the computer than to humans.

When students listened to their partners' recordings, they were quick to point out and correct their partner's incorrect pronunciations. They seemed to enjoy the feelings of being able to teach each other. Peer coaching became so natural when students used netbooks in class.

The classroom atmosphere was greatly enlivened in netbook-using class.

The participating teacher was especially encouraged by the positive effects brought about by the use of netbooks on students who were shy or withdrawn such as Sammy. It was observed that almost all students, including the shy ones, had fun recording and listening to their own voice. Hence, netbooks not only p rovided shy students with more opportunities for oral practices but helped to raise their interest in learning to such an extent that they seemed to have temporarily overcome their shyness.

Among the students who were interviewed at the end of the semester, more than threequarters of them felt that netbook-supported activities made the English language class much more fun than before and student-teacher interactions were also increased. 


\section{Observed classroom behaviour}

As mentioned previously, student behaviour was observed and recorded using a coded data sheet. Observation data were collected from 13 class periods for each group. A 40minute class period was divided into 3-minute intervals. At each 3-minute interval the observer marked on the recording sheet what behaviour (e.g. listening to lectures, taking notes, seeking help, doing listening practice) was observed for each student in class. Therefore, each student was observed 14 times during each class period, amounting to 182 observations (i.e. $14 \times$ 13) per student over the whole semester. These observations were tallied and converted into a percentage of time. For example, if students in a group (experimental or control) exhibited a specific identified behaviour at 245 intervals during 1000 observations, it was determined that the behaviour occurred 24.5 percent of the time for the group. The time sampling observations were reported as percentages in Figure 5. Statistically significant differences were found between the two groups in nine of the 12 categories of the observed behaviour. The three categories that did not show significant difference were peer discussion, answering teacher's questions, and reading practice.

As can be seen in Figure 5, students in the control group spent more than twice the amount of time listening to lectures. The netbook-using students in the experimental group, on the contrary, spent much more time on speaking practice $(26.4 \%$ vs. $5.9 \%)$ and listening practice $(10.1 \%$ vs. $6.8 \%)$. Apparently netbooks had provided students with more opportunities to practise listening and speaking. It was found from the qualitative data we collected that only a handful of students in the control group were frequently called on to practise speaking in class while most of others seldom had the chance.

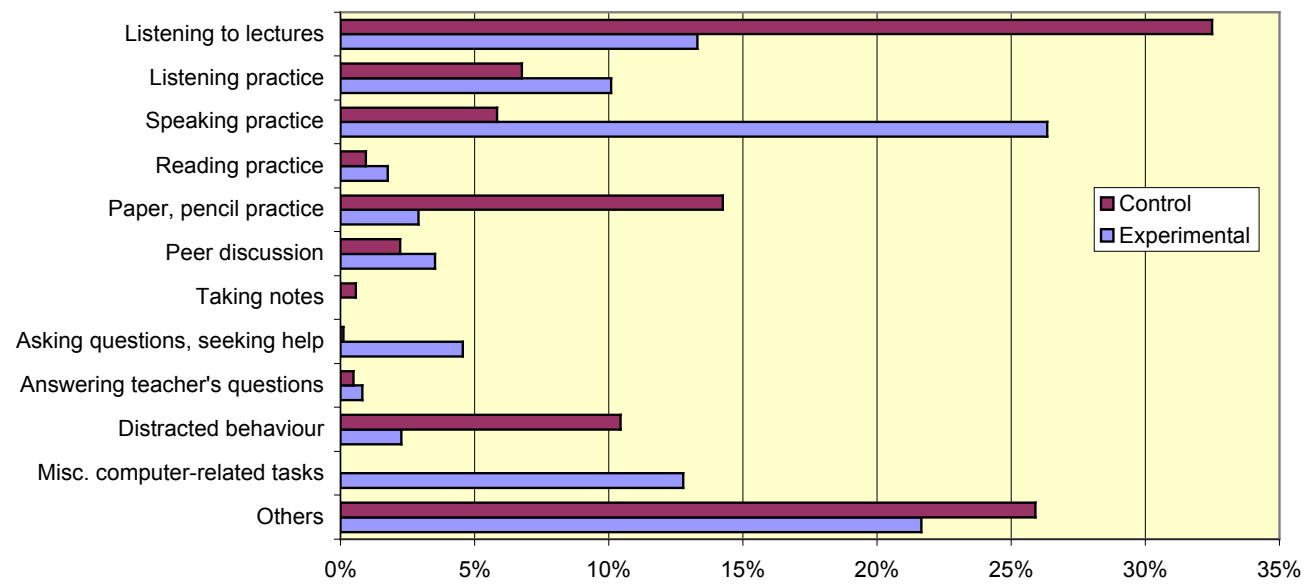

Figure 5: Time sampling observations reported as percentage

Students in the control group also exhibited distracted behaviour more often than those in the experimental group $(10.4 \%$ vs. $2.3 \%)$. This may seem somewhat unexpected because it is commonly believed that students can be easily distracted when they use computers in class. They may be tempted to visit websites or play computer games instead of listening to instructions/lecture or concentrating on the assigned tasks. According to our observations, the reason why these distracted 
behaviours seldom occurred in the experimental group was that netbook-using students usually had to pay great attention to the instructions given by the teacher, to be able to successfully complete a computer-enhanced task; besides, the learning activities were interesting enough to keep them on task. As Lei \& Zhao (2008) have reported, the issue of students not concentrating in class varied greatly from class to class and from teacher to teacher. Some teachers had effective strategies for monitoring students and were able to keep students engaged in their tasks. Apparently the teacher who participated in our study is one of these teachers.

It is also worth noting that students in the experimental group spent almost $5 \%$ of class time asking questions or seeking help, as compared to $0.1 \%$ for the control group. The qualitative data collected showed that most of their questions were about computer and network problems. If we further include the time (12.8\%) that netbook-using students spent on miscellaneous computer-related tasks such as turning on/off netbooks, connecting netbooks wirelessly to the network, and uploading/ downloading files, approximately one-sixth of class time was wasted on computerrelated tasks that had nothing to do with English learning. Even so, students in the experimental group did perform better in the final exam; their attitude toward learning English language was also more positive. These seem to justify the time overhead associated with the use of netbooks in class.

\section{Problems with implementing netbook-supported activities}

In addition to the mostly positive findings reported above, this study also revealed some problems with implementing netbook-enhanced learning activities. Firstly, wireless connectivity struggled when all netbooks tried to access the large multimedia files prepared by the teacher on the school Moodle system. There were always a few students who could not access the files successfully. These cases interrupted classroom activities and often caused frustration for both the teacher and the affected students. The teacher was finally forced to manually load each netbook with all the files needed for an activity before each class, which was both tedious and time-consuming. This confirms Cramer, Beauregard \& Sharma's claim (2009) that unreliable connectivity is a major barrier to effective classroom computing in general. Secondly, slow boot and application load time also increased classroom inefficiencies. As shown in Figure 5 above, a large portion of class time was spent on miscellaneous computer-related tasks that had nothing to do with English learning. It was later discovered that those netbooks that had slow boot time often contained free games which students downloaded from the Internet without teacher permission. Third, greater anxiety was experienced by the teacher because she felt the classroom activities were not entirely under her control when technology was involved. Fourth, not all parents welcomed the introduction of netbooks into the classroom for various reasons. Two major concerns were: (1) their children would learn less because too much time would be wasted on operating the computer, and (2) their children would be distracted by computer games and web content. It took extra time and effort to communicate with the parents at the beginning of the semester to obtain their consent.

\section{Conclusion}

In this paper we reported a study on integrating netbooks into sixth-grade English language classroom instruction in a Taiwanese elementary school. The instructor designed six netbook-supported learning activities for the 45 students in the 
experimental group, whilst 44 students in the control group received traditional instruction. It was found that, despite a few minor problems in implementing the netbook-supported instruction, netbook-using students not only performed significantly better in the final exam but had a more positive attitude toward learning English language. The use of netbooks provided students with more opportunities to practice speaking and listening in class, and students were more engaged in their work and exhibited less distracted behavior during class time.

In general, netbooks have allowed teachers to implement innovative, student-centred pedagogies. These encouraging findings further confirm the potential benefits of netbooks in language classrooms. As Penuel (2006) and Lei and Zhao (2008) have pointed out, aside from project evaluations, there has been little research-based evidence on the effectiveness of laptop initiatives on student learning. This study has attempted to provide arduously gathered quantitative and qualitative data to support our findings. However, a much larger-scale study would be needed to provide more evidence in this regard. Unfortunately, large-scale studies involving the use of netbooks are often beyond the capacity of individual researchers who typically are faced with limited research resources.

\section{References}

Barrios, T., Ambler, J., Anderson, A., Barton, P., Burnette, S., Feyten, C., Gallup, J., GonzalezBonnewitz, E., Harmes, J. C., Manderson, D. \& Miller, D. (2004). Final reports and recommendations of the laptops for learning task force. [viewed 20 April 2010]. http: / / www.flinnovates.org/ docs/LaptopsLearningFinalReport.pdf

Cramer, M., Beauregard, R. \& Sharma, M. (2009). An investigation of purpose built netbooks for primary school education. Proceedings of the 8th International Conference on Interaction Design and Children, 36-43.

Efaw, J., Hampton, S., Martinez, S. \& Smith, S. (2004). Miracle or menace: Teaching and learning with laptop computers in the classroom. EDUCAUSE Quarterly, 27(3), 10-18. http: / / www.educause.edu/EDUCAUSE+Quarterly / EDUCAUSEQuarterlyMagazineVolum /MiracleorMenaceTeachingandLear/157299

Godwin-Jones, R. (2008). Emerging technologies mobile-computing trends: Lighter, faster, smarter. Language Learning \& Technology, 12(3), 3-9. http: / / llt.msu.edu/vol12num3/emerging.pdf

Grimes, D., \& Warschauer, M. (2008). Learning with laptops: A multi-method case study. Journal of Educational Computing Research, 38(3), 305-332.

Hung, H.-C., Young, S. S.-C., \& Lin, C.-P. (2009). Constructing the face-to-face collaborative game-based interacted environment for portable devices in English vocabulary acquisition. Paper presented at the 8th International Conference on Computer Supported Collaborative Learning (CSCL 2009). June 8-13, 20009, Rhodes, Greece.

Lan, Y.-J., Sung, Y.-T., \& Chang, K.-E. (2007). A mobile-device-supported peer-assisted learning system for collaborative early EFL Reading. Language Learning E Technology, 11(3), 130-151. http: / /lt.msu.edu/vol11num3/pdf/lansungchang.pdf

Lei, J., \& Zhao, Y. (2008). One-to-one computing: What does it bring to schools? Journal of Educational Computing Research, 39(2), 97-122.

Lu, M. (2008). Effectiveness of vocabulary learning via mobile phone. Journal of Computer Assisted Learning, 24(6), 515-525. 
McGrail, E. (2006). "It's a double-edged sword, this technology business": Secondary English teachers' perspectives on a schoolwide laptop technology initiative. Teachers College Record, 108(6), 1055-1079.

Morgan, M. (2008). More productive use of technology in the ESL/EFL classroom. The Internet TESL Journal, 14(7). http:/ / iteslj.org/ Articles/ Morgan-Technology.html [viewed 20 April 2010].

Mouza, C. (2008). Learning with laptops: Implementation and outcomes in an urban, underprivileged school. Journal of Research on Technology in Education, 40(4), 447-472. http: / / www.eric.ed.gov:80/ERICWebPortal/ contentdelivery/ servlet/ERICServlet?accno=EJ 826086

Odhabi, H. (2007). Investigating the impact of laptops on students' learning using Bloom's learning taxonomy. British Journal of Educational Technology, 38(6), 1126-1131.

Penuel, W. R. (2006). Implementation and effects of one-to-one computing initiatives: A research synthesis. Journal of Research on Technology in Education, 38, 329-348. http:/ / www.eric.ed.gov :80/ERICWebPortal / contentdelivery / servlet/ERICServlet?accno=EJ728908

Rockman, S. (2003, Fall). Learning from laptops. Threshold Magazine, 24-28. [verified 11 Dec 2010] http://www.rockman.com/publications/articles/LearningFromLaptops.pdf

Silvernail, D. L. (2005). Does Maine's middle school laptop program improve learning? A review of evidence to date. Gorham, ME: Center for Education Policy, Applied Research \& Evaluation. http: / / www.usm.maine.edu/cepare/pdf/MLTI705.pdf [viewed 20 April 2010].

Suhr, K. A., Hernandez, D. A., Grimes, D. \& Warschauer, M. (2010). Laptops and fourth-grade literacy: Assisting the jump over the fourth-grade slump. The Journal of Technology, Learning, and Assessment, 9(5). http: / / www.jtla.org. [viewed 20 April 2010].

Thornton, P. \& Houser, C. (2005). Using mobile phones in English education in Japan. Journal of Computer Assisted Learning, 21(3), 217-228.

Warschauer, M., Grant, D., Del Real, G. \& Rousseau, M. (2004). Promoting academic literacy with technology: Successful laptop programs in K-12 schools. System, 32, 525-537.

Zucker, A. A. \& McGhee, R. (2005). A study of one-to-one computer use in mathematics and science instruction at the secondary level in Henrico County Public Schools. Washington, DC: SRI International. http: / / www.k12blueprint.com/k12/blueprint/cd/FinalReport.pdf [viewed 20 April 2010, verified 27 Dec 2010].

Professor Janet Mei-Chuen Lin PhD (corresponding author)

Graduate Institute of Information and Computer Education

National Taiwan Normal University

162 Hoping East Road, Section 1, Taipei, Taiwan 106

Email: mjlin@ntnu.edu.tw

Miss Yi-Jiun $\mathrm{Wu}$

Graduate Institute of Information and Computer Education

National Taiwan Normal University

162 Hoping East Road, Section 1, Taipei, Taiwan 106

Email: vmprmp@gmail.com 